\title{
THE ACTION OF FORMALIN ON MILK AND RENNET.*
}

\author{
BY DR. ERNST LÖWENSTEIN, Bertin.
}

THE changes which albuminoid bodies undergo when treated by formaldehyde were first described by Blum (1), who epitomizes the results of the "methylene combinations of albumin" as: "absence of coagulation on boiling a solution; great solubility in water; precipitation by acid, concentrated alcohol, or acetone when dissolved by recent addition of water."

Confirmation of this observation was soon made by Bach (2) and Benedicenti (3). The latter specially supplemented it in several directions. He placed gelatin, fibrin, blood serum, casein, and egg albumin for some time in contact with a solution of formalin, and ascertained by titration that a reduction of the quantity of formaldehyde in solution took place, and that the "formaldehyde proteids" were different from the original ones in essential points. Thus gelatin became hardened and insoluble, blood serum, like gall, fibrin and casein lost their power of absorption of fiuids, and along with egg albumin became indigestible. He also found that by heating in a current of steam the formaldehyde was split up, and the products regained their original characteristics.

Through v. Behring's proposal to employ formaldehyde as a milk preservative the question, in what way ascertainable by us the albuminous bodies in milk were affected by formalin became acute.

Already, in 1895, J. Rideal (4) and E. J. Bevan (5) had made an attempt to render formalined milk valuable from a hygienic point of view. The latter author made at the same time the interesting statement that formalined milk after some days showed an increase in weight of the dried residue, which apparently depends on the change of milk sugar into galactose, and that at the same time cane sugar appears to change into dextrose. As a matter of fact, later inquirers (Tollens, Lobry de Bruyer, and Ekerstein) have shown that the action of formaldehyde on the constitution of the different sugars is of the greatest importance. Th. Weigle and $\mathrm{S}$. Merkel confirm the statement that preservation of milk can take place by the addition of quantities of formalin which cannot be detected by either taste or smell, but that at the same time the casein of the milk undergoes an alteration. The change is also said by them to be of so fundamental a character that Gerber's method of determining the fat can no longer be used, since the casein cannot be dissolved in the mixture of sulphuric and acetic acids. The digestion by pepsin is not completely stopped, but delayed. The casein of formalined milk falls in thick, voluminous flocculi, for which reason milk which contains this gas should not be used as infants' food.

The activities of formaldehyde as portrayed by Weigle and Merkel were found by Muraközy to be subject to greater limitations. The observations of these authors were confirmed as far as the addition of the larger quantities of formalin were concerned (about 0.5 vol. per cent reckoned as pure aldehyde); but according to this author the amount of formalin necessary for preservative purposes is less than the amount which causes these changes. He makes, however, the extremely

* Zeitschrift für Hygiene und Infectionskrankheiten, vol. 48, part 1. Translated by Dr. R. K. Brown. 
interesting observation that the effect of formaldehyde on albuminous bodies increases. with the duration of the contact. The question as to how "formaldehyde proteids" behave towards digestive ferments was alluded to by Blum in his first publication.

According to Benedecenti, as already above remarked, the formaldehyde combination of all albuminous bodies examined by him, among which was casein, were not acted upon either by pepsin or trypsin. Other observers, such as Weigle and Merkel, Mabery and Goldsmith, and Lepierre, have only occupied themselves with peptic digestion, and have found that it was more or less delayed by formaldehyde.

The question has been further studied by Schwartz, under Hofmeister's direction, in the Strassburg Chemico-Physiological Institute, in an extremely thorough and comprehensive fashion. These excellent experimental enquiries showed that in the presence of an excess of formaldehyde trypsin failed to act, but that the activity of pepsin was interfered with, though not completely inhibited. They showed, moreover, that the albuminous preparations (Schwartz employed serumalbumin) in which no free aldehyde was demonstrable showed an almost absolute resistance to trypsin.

As a result of these experiments Schwartz came to the following conclusion :-

"Trypsin digestion is either partially or completely stayed by formaldehyde, and is adversely affected by acetaldehyde. The resisting power of combinations of albumin with aldehydes to tryptic digestion does not depend on this circumstance, since the traces of aldehyde which during the digestion of such preparations gradually become free, do not suffice for total inhibition of tryptic activity. From the fact that peptic digestion is maintained, one may suppose that either the attack on the albumin molecule by. the pepsin takes place at a different point from that of trypsin, or that during peptic digestion the hydrochloric acid renders those molecules already occupied by the aldehyde again free by the splitting up of the latter."

Taking this view as a foundation, the present work endeavours to demonstrate the changes which take place in milk as the result of adding those small quantities of formalin which are ordinarily used as a preservative. In preceding work on this subject large quantities of formalin have been exclusively used.

The behaviour of formalined milk towards the rennet ferment offered the shortest way of discovering the changes not demonstrable by chemistry, especially as the statement had already been made by Bliss and Novy that rennet no longer coagulates casein treated with formaldehyde.

For the purpose of this enquiry rennet powder (Witte) was used. This was dissolved in a 10 per cent salt solution, and the 1 per mille solution, after standing for twenty-four hours at room temperature, was filtered; $0.001 \mathrm{ccm}$. of this clear standard solution sufficed to coagulate $5 \mathrm{ccm}$. of milk in four hours. The estimation of the rennet, according to Morgenroth's method as employed by Fuld and Korschum, could not from external causes be employed, so the milk tests were simply placed in the incubator. The method of experimenting was as follows : From one sample of the milk to be experimented on a large number of test-tubes were filled, and at the same time mixed with increasing amounts of Schering's formalin. Next, rennet was added, the duration of the contact being varied in the different experiments. Further, each particular dilution of milk and formalin was tested three 
times, and observations made on the changes which take place by addition of 300,30 , and 3 times the minimal dose of rennet ferment. It may be premised to start with that the quantity of rennet to all appearance was of importance only in so far as it influenced the quickness of the reaction, for only in a few instances did the 300-fold dose of rennet give a more subtle indication of its incomplete action on the casein. The explanation of why the differences of result in the experiments of short duration are so striking; is that the action of the 3 -fold dose of rennet made its first appearance in three or four hours, so that in the more concentrated mixtures of formalin the action of the aldehyde takes place before that of the rennet.

TABLE I.-IMMEDIATE ADDITION OF RENNET FERMENT.

\begin{tabular}{|c|c|c|c|c|c|c|c|c|c|}
\hline \multirow{2}{*}{$\begin{array}{l}5 \text { ce. of Milk plus } \\
\text { Formalinreckoned } \\
\text { as pure Aldehyde. }\end{array}$} & \multicolumn{3}{|c|}{$\begin{array}{l}\text { 300-fold Minimum Doses } \\
\text { of Rennet. }\end{array}$} & \multicolumn{3}{|c|}{$\begin{array}{l}\text { 30-fold Minimum Doses } \\
\text { of Rennet. }\end{array}$} & \multicolumn{3}{|c|}{$\begin{array}{l}\text { 3-fold Minimum Doses } \\
\text { of Rennet. }\end{array}$} \\
\hline & $1 \mathrm{~h}$. & $\mathrm{a} \mathrm{h}$ & $6 \mathrm{~h}$. & $1 \mathrm{~h}$. & $3 \mathrm{~h}$. & $6 \mathrm{~h}$. & $1 \mathrm{~h}$. & $3 \mathrm{~h}$. & $6 \mathrm{~h}$. \\
\hline $1: 250$ & 0 & $+?$ & $+?$ & 0 & 0 & 0 & 0 & 0 & 0 \\
\hline $1: 500$ & $+?$ & + & & 0 & + & & 0 & + & \\
\hline $1: 850$ & $+?$ & + & & + & & & 0 & + & \\
\hline $1: 1250$ & + & & & + & & & 0 & + & \\
\hline $1: 2500$ & + & & & + & & & 0 & + & \\
\hline $1: 5000$ & + & & & + & & & 0 & + & \\
\hline $1: 8500$ & + & & & + & & & 0 & + & \\
\hline $1: 12500$ & + & & & + & & & 0 & + & \\
\hline $1: 25000$ & + & & & + & & & 0 & + & \\
\hline Control I. & + & & & + & & & 0 & + & \\
\hline , II. & + & & & + & & & 0 & + & \\
\hline III. & + & & & + & & & 0 & + & * \\
\hline
\end{tabular}

TABRE II.-RENNET ADDED AFTER TWO HOURS.

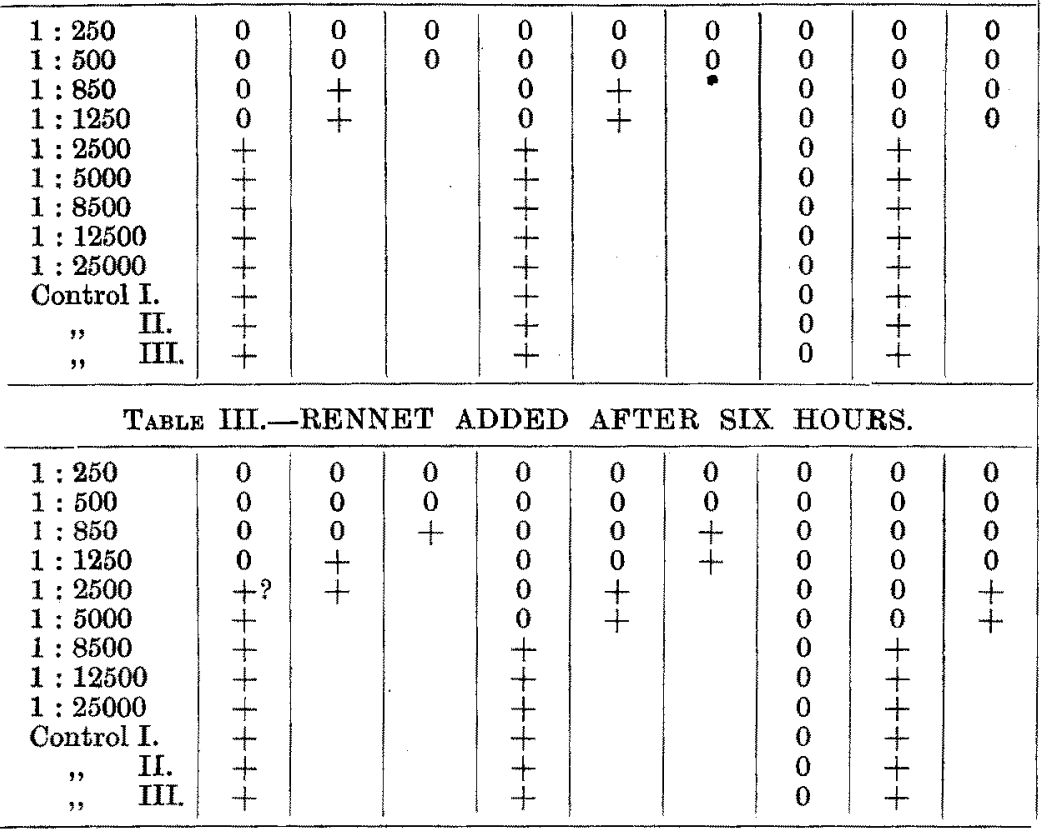


TABLE IV.-RENNET ADDED AFTER TWENTY-FOUR HOURS.

\begin{tabular}{|c|c|c|c|c|c|c|c|c|c|}
\hline \multirow{2}{*}{$\begin{array}{l}5 \text { ce. of Milk plus } \\
\text { Formalin reckoned } \\
\text { as pure Aldehyde. }\end{array}$} & \multicolumn{3}{|c|}{$\begin{array}{l}\text { 300-fold Minimum Doses } \\
\text { of Rennet. }\end{array}$} & \multicolumn{3}{|c|}{$\begin{array}{l}\text { 30-fold Minimum Doses } \\
\text { of Rennet. }\end{array}$} & \multicolumn{3}{|c|}{$\begin{array}{l}\text { 3-fold Minimum Doses } \\
\text { of Rennet. }\end{array}$} \\
\hline & $1 \mathrm{~h}$. & $3 \mathrm{~h}$. & $6 \mathrm{~h}$. & $1 \mathrm{~h}$. & $3 \mathrm{~h}$. & $6 \mathrm{~h}$. & $1 \mathrm{~h}$. & $3 \mathrm{~h}$. & $6 \mathrm{~h}$. \\
\hline $1: 250$ & 0 & 0 & 0 & 0 & 0 & 0 & 0 & 0 & 0 \\
\hline $1: 500$ & 0 & 0 & 0 & 0 & 0 & 0 & 0 & 0 & 0 \\
\hline $1: 850$ & 0 & 0 & 0 & 0 & 0 & 0 & 0 & 0 & 0 \\
\hline $1: 1250$ & 0 & $+?$ & + & 0 & $+?$ & + & 0 & 0 & $+?$ \\
\hline $1: 2500$ & 0 & + & & 0 & + & & 0 & 0 & 0 \\
\hline $1: 5000$ & + & & & + & & & 0 & 0 & \\
\hline $1: 8500$ & + & & & + & & & 0 & + & \\
\hline $1: 12500$ & + & & & + & & & 0 & + & \\
\hline $1: 25000$ & + & & & + & & & 0 & + & \\
\hline Control I. & + & & & + & & & 0 & + & \\
\hline , II. & + & & & + & & & 0 & + & \\
\hline , III. & + & & & + & & & 0 & + & \\
\hline \multicolumn{4}{|c|}{ TABLE V.RENNET ADDED } & \multicolumn{6}{|c|}{ AFTER FORTY-EIGHT HOURS. } \\
\hline $1: 250$ & 0 & 0 & 0 & 0 & 0 & 0 & 0 & 0 & 0 \\
\hline $1: 500$ & 0 & 0 & 0 & 0 & 0 & 0 . & 0 & 0 & 0 \\
\hline $1: 850$ & 0 & 0 & 0 & 0 & 0 & 0 & 0 & 0 & 0 \\
\hline $1: 1250$ & 0 & 0 & $+?$ & 0 & 0 & 0 & 0 & 0 & 0 \\
\hline $1: 2500$ & 0 & + & & 0 & + & & 0 & $+?$ & $+?$ \\
\hline $1: 5000$ & + & & & 0 & + & & 0 & 0 & $+?$ \\
\hline $1: 8500$ & + & & & 0 & + & & 0 & 0 & + \\
\hline $1: 12500$ & + & & & + & & & 0 & + & \\
\hline $1: 25000$ & + & & & + & & & 0 & + & \\
\hline Control I. & + & & & + & & & 0 & + & \\
\hline , II. & + & & & + & & & 0 & + & \\
\hline " III. & + & & & + & & & 0 & + & \\
\hline \multicolumn{10}{|c|}{ TABLE VI.-RENNET } \\
\hline \multirow{2}{*}{ Formalin. } & \multicolumn{3}{|c|}{$\begin{array}{l}\text { 300-foid Minimum Dose } \\
\text { of Rennet. }\end{array}$} & \multicolumn{3}{|c|}{$\begin{array}{l}\text { 30-fold Minimum Dose } \\
\text { of Rennet. }\end{array}$} & \multicolumn{3}{|c|}{$\begin{array}{l}\text { 3-fold Minimum Dose } \\
\text { of Rennet. }\end{array}$} \\
\hline & Ih. & $3 \mathrm{~h}$ & $6 \mathrm{~h}$. & $1 \mathrm{~h}$. & $3 \mathrm{~h}$. & $6 \mathrm{~h}$. & in. & $3 \mathrm{~h}$. & $6 \mathrm{~h}$. \\
\hline $1: 250$ & 0 & 0 & 0 & 0 & 0 & 0 & 0 & 0 & 0 \\
\hline $1: 500$ & 0 & 0 & 0 & 0 & 0 & 0 & 0 & 0 & 0 \\
\hline $1: 850$ & 0 & 0 & 0 & 0 & 0 & 0 & 0 & 0 & 0 \\
\hline $1: 1250$ & 0 & 0 & 0 & 0 & 0 & 0 & 0 & 0 & 0 \\
\hline $1: 2500$ & 0 & 0 & 0 & 0 & 0 & 0 & 0 & 0 & 0 \\
\hline $1: 5000$ & 0 & 0 & $t$ & 0 & 0 & 0 & 0 & 0 & 0 \\
\hline $\begin{array}{l}1: 12500 \\
1: 25000\end{array}$ & \multicolumn{9}{|c|}{ \} spontaneons coagulation. } \\
\hline
\end{tabular}

If one follows the behaviour of the formalined milk in the experiment with the 3-fold minimum dose, which strength exhibits to the best advantage the more subtle changes in the casein, the results as set forth below take place.

To sum up the results shown in the foregoing tables: The changes which milk undergoes through the addition of formaldehyde are the more far-reaching the longer the action of the formaldehyde continues.

If rennet and formalin are added to the milk at the same time, coagulation sets in at a strength of 1 in 250 (that is, $0.05 \mathrm{ccm}$. Schering's formalin to $5 \mathrm{ccm}$. milk). If the rennett is added six hours after the formalin: there is considerable postponement of coagulation; if after twenty-four hours, the coagulation will take place with a dilution of 
THE THREE-FOLD MINIMUM DOSE OF RENNET PRODUCES COAGULATION IN FOUR HOURS.

\begin{tabular}{l|c|c|c|c|c|c}
\hline $\begin{array}{c}\text { Proportion } \\
\text { between } \\
\text { Formalin } \\
\text { and Milk. }\end{array}$ & $\begin{array}{c}\text { Immediate } \\
\text { Addition } \\
\text { of Reunet } \\
\text { Ferment. }\end{array}$ & $\begin{array}{c}\text { After } \\
\mathbf{2} \mathrm{h} .\end{array}$ & $\begin{array}{c}\text { After } \\
6 \mathrm{~h} .\end{array}$ & $\begin{array}{c}\text { After } \\
\mathbf{2 4} \mathrm{h} .\end{array}$ & $\begin{array}{c}\text { After } \\
\mathbf{4 8} \mathrm{h} .\end{array}$ & $\begin{array}{c}\text { After } \\
96 \mathrm{~h} .\end{array}$ \\
\hline $1: 500$ & + & 0 & 0 & 0 & 0 & 0 \\
$1: 5000$ & + & + & + & 0 & 0 & 0 \\
$1: 8500$ & + & + & + & + & + & + \\
$1: 12500$ & + & + & + & + & + & + \\
\hline
\end{tabular}

Nore. -0 , signifies no action; + , signifies reaction; $h$, signifies hours.

1 in 1250 ; if after forty-eight hours and ninety-six hours, the same result is obtained with dilutions of 1 in 2500 and 1 in 5000 respectively. Greater dilutions of formalin could not be used in these experiments, since spontaneous clotting of the milk always sets in after from 96 to 120 hours.

In any case the result of these experiments shows that through a contact lasting four days, even in a proportion of 1 in 5000 formalin, the milk is so altered that it no longer reacts to rennet.

There is no doubt also that during the continuance of the contact of formalin and milk the changes in the constitution of the milk-albumin progress. No great weight can therefore be attributed to the view that possibly the absence of coagulation can be referred to the alteration of the rennet ferment by the formaldehyde. The above experiments justify the view expressed here.

Freudenreich has already pointed out in his work entitled "Contributions to our knowledge of Rennet" that in order to sterilize this ferment a 1 per cent solution of formaldehyde is necessary, and that even this amount does not produce any essential weakening of its activity. My own observations have shown that rennet ferment is extraordinarily resistant to formalin. One ccm. of the above-mentioned standard solution (of rennet) was mixed with undiluted quantities of formalin and five tests made :-

$$
\begin{aligned}
& \text { 1. }-1 \mathrm{ccm} \text {. rennet solution }+1 \mathrm{ccm} \text {. formalin }
\end{aligned}
$$

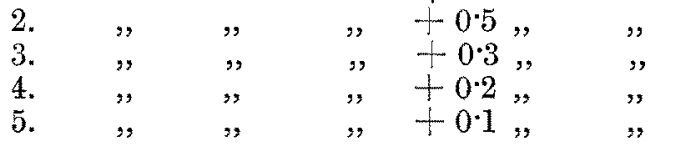

The fermentative value of the rennet was estimated by titration after each single test of eight, twenty-four, and seventy-two hours' duration respectively by further diluting $0.1 \mathrm{ccm}$. the original mixture (Stammeprouvette). This showed that even after seventy-two hours in experiment No. 2 (viz. $1 \mathrm{ccm}$. rennet and $0.5 \mathrm{ccm}$. formalin) the rennet suffered practically no.loss of activity.

On the other hand, the fermentative action is completely arrested when rennet powder is exposed for long to an atmosphere of formaldehyde. This striking result, which E. Freudenreich published in 1898, rests on a sure footing, for 1 gram of Witte's rennet powder was exposed for twenty-four hours in a glass bell-jar to an atmosphere of formaldehyde. The dry powder became moist, crumbling, and adherent to the jar; then 0.1 gram of this was dissolved in 100 ccms. of a 10 per cent salt 
solution (solution taking place readily), and it was found that this solution had lost all fermentative activity.

As regards the other ferment, one may mention the experiments of C. L. Bliss and F. S. Novy, which show according to their statements that papain is easily, but trypsin and amylopsin with difficulty, disturbed by formaldehyde.

The latter ferments bear weak solutions of formaldehyde at roomtemperature, but are much more sensitive to it at $40^{\circ} \mathrm{C}$. Pepsin and diastase, on the contrary, can resist the action of 5 per cent formaldehyde for weeks without loss of activity.

While solutions of diastase without formaldehyde become neutralized by the action of bacteria, the action of the enzyme is said to continue in the presence of these by the addition of formalin.

S. Sawamura questioned these observations, for he found the activity of a commercial pepsin preparation which was put for twenty-four hours in a 10 per cent formaldehyde solution completely destroyed. The different results of these enquirers and like statements made by Pekelharing led Sawamura to the conclusion that these authors had employed diluted formaldehyde and allowed these to work on the pepsin, not in a neutral solution, but in one free from salt.

To settle the question whether the activity of a ferment is disturbed by formaldehyde it is recommended to allow the formaldehyde to act in gas form, since in this way disturbing factors are excluded. The incongruence in the results of the experiments of the employment of formalin in gas and in solution. on pepsin, demands that similar experiments should be conducted with other ferments. In this way can the existing uncertainties be set at rest.

\section{Conclusions:}

1. Formaldehyde so alters the milk that it no longer reacts towards rennet. The degree of alteration depends, first, on the length of contact, and, secondly, on the strength of the formalin solution.

2. These changes in the milk take place with the small quantities of formalin which are used in practice for preservation.

3. Formaldehyde in solution does not rob the salt solution of rennet of its activity, while formaldehyde in gas form does this.

P.S.- The author mentions that Dr. Monekton Copeman attributed an epidemic skin disease in Hendon Hospital to formalined milk.

The Poulution of the River Isar.-The view of Professor Pettenkofer and his colleagues that, in consequence of the effects of self-purification, the river Isar is capable of dealing with the whole of the sewage of Munich, is controverted by Professor Hofer, and it is stated in the GesundheitsIngenieur that the results of extensive sewage pollution may now be traced as far below Munich as the junction of the Isar with the Danube, a distance of upwards of sixty miles. Both the diseolouration and the turbidity of the river water have become greatly increased during recent years, and vast banks of mud and sediment have been formed in the river bed. Bacteriological tests have shown that a certain amount of improvement in the quality of the water, due probably to self-purification, is apparent, but the analyses indicate that the bacteria do not, as supposed, lead to the mineralization of the organic matter in solution. Quite the contrary is, in fact, the case, and enormous growths of fungi are found all down the stream, while the bed of the river has undergone an amazing change. 